O.O. Gudaryan, I.S. Mashchenko, T.O. Kucherenko

\section{TREATMENT OF AGGRESSIVE (RAPIDLY PROGRESSING) GENERALIZED PERIODONTITIS USING SYSTEMIC ENZYME THERAPY IN COMBINATION WITH OSTEOINDUCTIVE MEDICINES}

\author{
SE «Dnipropetrovsk medical academy of Health Ministry of Ukraine» \\ Department of surgical dentistry, implantology and periodontology \\ V. Vernadsky str., 9, Dnipro, 49044, Ukraine \\ ДЗ «Дніпропетровська медична академія МОЗ Украӥни» \\ кафедра хірургічної стоматології, імплантологї̈ та пародонтології \\ (зав. - д.мед.н. дои. Н.Г. Ідашкіна) \\ вул. В. Вернадського, 9, Дніпро, 49044, Украӥна \\ Email: taraskomer@gmail.com
}

Цитування: Медичні перспективи. 2020. Т. 25, № 3. С. 144-152

Cited: Medicni perspektivi. 2020;25(3):144-152

Key words: generalized periodontitis, aggressive periodontitis, systemic enzyme therapy, Wobenzym, recombinant morphogenetic protein, rhBMP-2, treatment of periodontitis

Ключові слова: генералізований пародонтит, агресивний пародонтит, системна ензимотерапія, Вобензим, рекомбінантний морфогенетичний білок, rhBMP-2, лікування пародонтиту

Ключевые слова: генерализованный пародонтит, агрессивный пародонтит, системная энзимотерапия, Вобэнзим, рекомбинантный морфогенетический белок, rhBMP-2, лечение пародонтита

\begin{abstract}
Treatment of aggressive (rapidly progressing) generalized periodontitis using systemic enzyme therapy in combination with osteoinductive medicines. Gudaryan O.O., Mashchenko I.S., Kucherenko T.O. The modern treatment strategy for various forms of generalized periodontitis includes the use of a wide arsenal of drugs, which in turn leads to an excessive drug load on the body, this actualizes the search and use of drugs that have a systemic effect. The aim of the study is to develop and study the effectiveness of the use of systemic enzyme therapy in the treatment of aggressive (rapidly progressing) generalized periodontitis. The work is based on the results of comprehensive clinical and laboratory studies of 61 patients with an aggressive form of generalized periodontitis, without concomitant pathologies (30 - in main group and 31 - in comparison group). A control group consisted of 20 healthy donor volunteers. We used standard clinical, paraclinical, laboratory diagnostic methods, supplemented by dental volumetric tomography. In patients of both observation groups, standard protocol therapy was used, in the comparison group supplemented pathogenic therapy, and in the main group - multienzyme drug (Wobenzym) and rhBMP-2 injections. A comparative analysis of clinical, paraclinical, and laboratory studies has shown that the use of systemic enzyme therapy supplemented with recombinant morphogenetic protein (rhBMP-2) in patients with aggressive (rapidly progressing) generalized periodontitis is comparable to that of standard polymedicine therapy supplemented with pathogenic therapy, and leads to a faster control (average 13.7 10.7 days) of an active inflammatory and destructive process, normalization of indices of local humoral immunity, cytokine profile, free radical oxidation and antioxidant defense system, achievement of clinical and radiological remission in more than $90 \%$ of patients.
\end{abstract}

Реферат. Лечение агрессивного (быстро прогрессирующего) генерализованного пародонтита с использованием системной энзимотерапии в комбинации с остеоиндуктивными средствами. Гударьян А.А., Мащенко И.С., Кучеренко Т.А. Современная стратегия лечения различных форм генерализованного пародонтита включает в себя использование широкого арсенала лекарственных препаратов, что в свою очередь приводит к чрезмерной медикаментозной нагрузке на организм, что актуализирует поиск и применение препаратов, обладающих системным действием. Целью исследования является разработка и изучение эффективности использования системной энзимотерапии в лечении агрессивного (быстропрогрессирующего) генерализованного пародонтита. В основу работы положень результаты комплексных клинических и лабораторных исследований 61 паџиента с агрессивной формой генерализованного пародонтита, без сопутствующих патологий (30 - основной группь и 31 - группы сравнения). Контрольную группу составили 20 здоровых доноров-добровольцев. Были использованы стандартные клинические, параклинические, лабораторные методы диагностики, дополненные дентальной объемной томографией. У больных обеих групп наблюдения применялась стандартная протокольная терапия, дополненная в группе сравнения пато- 
генетической терапией, а в основной группе полиферментным препаратом (Вобэнзим) и инъекииями rhВмР-2. Сравнительный анализ клинических, параклинических и лабораторных исследований показал, что использование системной энзимотерапии, дополненной рекомбинантным морфогенетическим белком (rhBMP-2), y больных с агрессивным (быстропрогрессирующим) генерализованным пародонтитом сопоставима с таковой при применении стандартной полимедикаментозной терапии, дополненной патогенетической терапией, $u$ приводит к более быстрому купированию (в среднем 13,7士0,7 дня) активного воспалительно-деструктивного процесса, нормализации показателей местного гуморального иммунитета, ичитокинового профиля, свободнорадикального окисления и антиоксидантной системы защитты и достижению клинико-рентгенологической ремиссии более чем у $90 \%$ больных.

Generalized periodontitis is one of the most widespread dental diseases, which leads to significant loss of teeth (up to $80 \%$ ) in young and middleaged people and negatively affects the general state of human health. According to the WHO, the highest level of this pathology is recorded in the age group from 35 to 44 years old and in persons from 45 to 60 years old, where it is revealed in at least $50 \%$ of cases [4].

According to current views, a modern strategy for the treatment of generalized periodontal disease should provide for the correction of the main pathogenetic factors that potentiate the progressive development of destructive manifestations in the gingival and bone structures of the periodontium, among which various pathogens, disorders of local humoral immunity, imbalance of cytokine status, radical lipid oxidation and antioxidant defense system play a leading role $[3,6,7]$.

This approach requires a simultaneous use of a wide arsenal of medicinal preparations (antibacterial, anti-inflammatory, immune-sensitive and antioxidant agents), the choice of which for inclusion in the generally accepted treatment protocol is rather difficult. Considering ambiguous polysystemic disorders, they can be different in different options for generalized periodontitis and are not always detected in a specific pathology $[5,8,11]$.

This is especially true for acute and aggressive (rapidly progressing) forms of generalized periodontitis. It is the lack of understanding of the main mechanisms of their development that is still the subject of controversy, and this does not allow conducting targeted pathogenetic therapy in full and with a certain success. In addition, there is insufficient understanding of the nature of bone metabolism in these patients, the mechanisms of osteoresorption and osseogenesis and methods of their correction.

Considering the excessive drug pressure on the body as a whole, in the implementation of the necessary pathogenetic polytherapy of the aggressive variant of generalized periodontitis, an urgent aspect is the search for drugs that have a systemic effect and their inclusion in the protocol for the treatment of this complex pathology. It is all the more important that the issue raised in recent years has been successfully developed by a foreign school of scientists $[9,10,11]$. The main result of the research is the authors' assumption, if possible, to abandon a simultaneous prescription of a wide arsenal of medications in the treatment of a number of diseases and the transition to monotherapy, which can be equally effective and safer.

According to literature data, such universal preparations include Wobenzim ${ }^{\circledR}$, which contains enzymes of animal and plant origin that cause antiinflammatory, dehydrative, antitoxic, immunomodeling effects. The positive effects of systemic enzyme therapy (SET) are also associated with their ability to eliminate tissue hypoxia, improve microcirculation and metabolic processes, and ultimately to cause a significant and positive effect on the quality of tissue regeneration in the area of inflammatory and destructive lesions $[2,9]$. No less important is the fact that SET will enhance the effect of antimicrobial drugs.

All of the above justifies the need to study the feasibility of using monotherapy with Wobenzym together with protocol antibacterial therapy as a pathogenetic treatment of rapidly progressing generalized periodontitis.

The aim of the study was to develop and study the effectiveness of the use of systemic enzyme therapy in the treatment of aggressive generalized periodontitis.

\section{MATERIALS AND METHODS OF RESEARCH}

The work is based on the materials of a complex clinical and laboratory examination and follow-up observation for 12 months or more of 61 patients aged 35 to 50 years (average age $47.6 \pm 2.4$ years) with aggressive (rapidly progressing) generalized parodontitis, I-II degree of severity. Among them, $41(67.2 \%)$ women and $20(32.8 \%)$ men were observed. The control group consisted of 20 healthy volunteer donors with intact teeth and periodontium, approximately similar in sex and age percentage.

All patients and control subjects were included in the study only after informed consent to the planned clinical, laboratory and treatment activities. At the 
time of examination on the basis of anamnestic data and the conclusions of other specialists no concomitant pathology that required medical treatment was revealed in any patient.

The diagnosis was made on the basis of clinical and radiological criteria presented in the domestic classifications of inflammatory periodontal diseases (N.F. Danilevsky, A.V. Borisenko, 1994; I.S. Mashchenko, 2003).

Upon admission to the clinic, general blood and urine tests, biochemical blood tests for sugar, tests for HIV and hepatitis were performed. Subsequently, all patients underwent dynamic observation of conventional clinical and paraclinical examination which included: collection of complaints, history, determination of allergy status, visual and instrumental assessment of gingival tissue, detection of bleeding, edema, hyperemia, granulations, purulent exudate and abscesses, the presence of discomfort when chewing, etc.

The index of oral hygiene was studied according to the method of Green V.C. Vermilion, the intensity and prevalence of the inflammatory process in periodontal tissues were determined by the degree of bleeding from the gingival sulcus (Muhlemann $\mathrm{H}$. Cowell, 1975) and by the papillary-marginalalveolar index (PMA), modified by C. Parma in 1960. To objectify the severity and prevalence of inflammatory and destructive changes in periodontal tissues periodontal index (PI) according to Russel (1956) was used.

The depth of periodontal pockets was measured in the traditional way using a Goldman-Fox probe and the Florida Probe system.

To clarify the diagnosis and dynamics of the destructive process in the bone structures of the periodontium, orthopantomography and volumetric computed tomography were performed on a Planmeca Pro Max radiation tomograph (Finland).

Laboratory research included determination of the content of secretory immunoglobulin A (SIgA), immunoglobulins A, G and M (IgA, IgG and IgM), levels of basic regulatory interleukins (IL-1 $\beta$, TNF$\alpha$, IL-4) and the state of radical oxidation lipids and antioxidant defense system.

The content of immunoglobulins of the main classes in the oral fluid was determined by solidphase enzyme-linked immunosorbent assay using monospecific standard antisera against immunoglobulins of the main classes of test systems of "Protein Contour", "Polygnost" (St. Petersburg).

Quantitative assessment of the levels of cytokines IL- $1 \beta$, TNF- $\alpha$ and IL-4 in gingival fluid was performed by the method of solid-phase enzyme-linked immunosorbent assay using reagents from "Protein
Contour", "Polygnost" (St. Petersburg) on the automatic washer Stat Wash 2600 (Stat Fax, Usa) of the orbital type with a speed of 400-700 RPM. The results of the analysis were taken into account spectrophotometrically using a microplate photometer Stat Fax 2100 (Stat Fax, USA) at a wavelength of $450 \mathrm{~nm}$.

The study of lipid peroxidation (LPO) was carried out by determining the levels of concentration of lipid hydroperoxides (LHP) and malonic dialdehyde (MDA) in blood plasma (V.B. Gavrilov et al., 1987).

To assess the antioxidant status, the activity of individual elements of the antioxidant system was determined: the level of superoxide dismutase (SOD) and catalase in gingival erythrocytes by the method of S. Chevar et al. (1991).

In the study, patients with rapidly progressing generalized periodontitis were randomly divided into two groups: main (group I) - 30 people, comparison (group II) - 31 people, which were compared by age, sex, clinical and paraclinical features and baseline radiological and laboratory data, which made it possible to assess the effectiveness of the therapy used from the standpoint of evidence-based medicine.

At the initial stage of treatment, patients of both groups underwent uniform treatment measures in accordance with the standards adopted at this time: training in controlled individual oral hygiene, professional hygienic interventions, combined of the same type antibacterial therapy was used: topically, drugs containing chlorhexidine orally - Amoxiclav $875 \mathrm{mg}$ daily for 6-7 days.

Subsequently, patients of the comparison group, with taking into account the identified and precised pathogenetic mechanisms of the disease, received additional complex immunocorrective therapy (Polyoxidonium and Likopid), antioxidant Mexidol and osteoinductive drug Osteogenon in conventional doses and according to the recommended treatment regimens.

Patients in the main group, were administered a polyenzyme preparation Wobenzym ${ }^{\circledR}$ (manufactured by Mucos Pharma Gmbh, Germany), represen ting a combination of highly active enzymes to the treatment protocol along with traditional occupational hygiene measures and protocol antibacterial therapy instead of those used in the comparison group of pathogenetic therapy. They were prescribed 4 tablets of the drug 30-40 minutes before meals, three times a day for 25-30 days. To enhance osseogenesis in the main group morphogenetic protein (rhBMP-2) with injectable concentrate of autologous i- 
PRF (1 to 3) in two injections into the submandibular with an interval of 6-7 days was used.

Evaluation of treatment results was performed immediately after the end of all treatment measures, three, six months or more from the beginning of therapy.

Statistical analysis of the results of the study was performed using computer programs Microsoft Excel 2010 (license number 02260-018-000010648794) and Statistica 6.1 (serial number AGAR909E415822FA). Statistical data processing was performed by methods of variation statistics with calculation of arithmetic mean values (M), standard deviation $(t)$, standard error of mean $(m)$. In case of confirmation of the normal distribution law when comparing quantitative indicators between groups, we used parametric methods - Student's ttest for independent variables, and to identify differences in dynamics during treatment, Student's t-test for dependent variables.

If the normal distribution law was not confirmed, nonparametric methods were used when comparing quantitative indicators: groups were compared in pairs using the Mann-Whitney U-test, and Wilcoxon's T-test was used to detect differences in the dynamics during treatment. The critical level of statistical significance of the null hypothesis was taken at $\mathrm{p}<0.05$ [1].

\section{RESULTS AND DISCUSSION}

The analysis of clinical results showed that in patients of both groups under the influence of medical complexes there was achieved the elimination of inflammatory processes in the periodontium approximately at the same time, this was manifested in the disappearance of complaints of pain and gums bleeding, absence of hyperemia of gingival mucosa tissues, exudate from periodontal pockets, restoring of relief and density of the gingival margin.

Under their influence a complete elimination of inflammatory phenomena in periodontal tissues was observed in $93.5 \%$ of patients in the comparison group on day 14-16 of treatment (average 15.2 \pm 0.6 days) and in $96.6 \%$ of patients in the main group up to 12-14 days (on average 13.7 \pm 0.7 ). An objective study conducted at this time revealed the mucous membrane of the marginal part of the gums was rose- pink, tightly covering the neck of the tooth, no bleeding and a significant decrease in gingival and periodontal indices (Table 1).

The hygiene index improved equally in patients of both groups and remained at the same level for 12 months demonstrating good oral hygiene.

The obtained data on the state of bleeding gums indicated the absence or reduction of inflammatory phenomena in all patients, which testified to a high clinical efficacy of the drugs used in the treatment of rapidly progressing generalized periodontitis. Here it is appropriate to note that 6 and 12 months after treatment, the levels of the bleeding index in patients of the main and the comparison group did not change $(\mathrm{p}<0.05)$.

At the end of treatment, there was a significant decrease in the value of the papillary-marginalalveolar index which decreased by $68.6 \%$ in patients of the comparison group and by $70.4 \%$ in patients of the main group. After the end of treatment in 6 and 12 months the analyzed indicator did not change significantly - this indicates the absence of exacerbations or recurrences of the inflammatory process in the periodontium during this period. Immediately after treatment in patients of both groups there was a decrease in the value of the periodontal index by almost 2 times: in patients of the comparison group - by 2.3 times, in patients of the main group - by 2.26 times respectively. The maximum decrease in the periodontal index was noted after 12 months of follow-up, which indicated not only the full elimination of inflammatory and destructive phenomena in the periodontium but also the long-term remission of the achieved treatment results.

Along with this, after the treatment there was a decrease in the depth of periodontal pockets: in the main group to $3.6 \pm 0.09 \mathrm{~mm}$ against $5.72 \pm 0.7 \mathrm{~mm}$ before treatment, and in the comparison group - to $3.1 \pm 0.6 \mathrm{~mm}$ against $5.69 \pm 0.6 \mathrm{~mm}$ due to the elimination of the inflammatory process in the gingival tissue $(p<0.05)$. In patients of both groups 6 and 12 months after treatment, the depth of periodontal pockets had a pronounced tendency to further decrease (Table 1).

The degree of teeth mobility in the remote period of observation is of particular note. During the instrumental examination, the first degree of mobility was detected in $75.9 \%$ of cases, the second degree - in $20.5 \%$ of cases and the third degree - in $3.4 \%$ of cases. No significant differences in this feature between the main and the comparison group were found $(\mathrm{p}<0.05)$. This pattern, of course, is associated with events in the remote terms of observations, regenerative processes in the bone structures of the periodontium and the absence of recurrence of inflammation in periodontal tissues.

Thus, the total clinical and index assessment of the effectiveness of treatment complexes in the main and comparison groups did not reveal a significant and reliable advantage of any of them. The use of protocol therapy supplemented with 
Osteogenon and the use of Wobenzyme in combination with rhBMP-2 in patients with rapidly progressing periodontitis was justified in terms of short-term and long-term clinical outcomes, which is especially important and confirmed by radiological data.

Dynamics of periodontal indices and samples in patients with rapidly progressing generalized periodontitis of the main and comparison group (M $\pm m)$

\begin{tabular}{|c|c|c|c|c|c|c|c|c|}
\hline \multirow{3}{*}{$\begin{array}{l}\text { Clinical and } \\
\text { paraclinical } \\
\text { indicators of } \\
\text { periodontal } \\
\text { tissue condition }\end{array}$} & \multicolumn{8}{|c|}{ Groups of subjects } \\
\hline & \multicolumn{4}{|c|}{ Comparison group $(n=31)$} & \multicolumn{4}{|c|}{ Main group $(n=30)$} \\
\hline & $\begin{array}{c}\text { before } \\
\text { treatment }\end{array}$ & $\begin{array}{l}1 \text { month } \\
\text { after } \\
\text { treatment }\end{array}$ & $\begin{array}{l}6 \text { months } \\
\text { after } \\
\text { treatment }\end{array}$ & $\begin{array}{l}12 \text { months } \\
\text { after } \\
\text { treatment }\end{array}$ & $\begin{array}{c}\text { before } \\
\text { treatment }\end{array}$ & $\begin{array}{c}1 \text { month } \\
\text { after } \\
\text { treatment }\end{array}$ & $\begin{array}{l}6 \text { months } \\
\text { after } \\
\text { treatment }\end{array}$ & $\begin{array}{l}12 \text { months } \\
\text { after } \\
\text { treatment }\end{array}$ \\
\hline $\begin{array}{l}\text { Hygiene index } \\
\text { OHI-S (in points) }\end{array}$ & $3.43 \pm 0.1$ & $0.72 \pm 0.12 *$ & $0.81 \pm 0.1 *$ & $0.8 \pm 0.1^{*}$ & $3.44 \pm 0.09$ & $0.68 \pm 0.1^{*}$ & $0.74 \pm 0.11 *$ & $0.78 \pm 0.12 *$ \\
\hline $\begin{array}{l}\text { Bleeding index } \\
\text { SBI (in points) }\end{array}$ & $2.64 \pm 0.04$ & $0.56 \pm 0.02 *$ & $0.46 \pm 0.02 *$ & $0.48 \pm 0.03 *$ & $2.54 \pm 0.04 *$ & $0.41 \pm 0.02 *$ & $0.40 \pm 0.02 *$ & $0.66 \pm 0.03 *$ \\
\hline PMA index (\%) & $74.6 \pm 2.8$ & $4.2 \pm 0.08 *$ & $4.6 \pm 0.08 *$ & $8.8 \pm 0.2 *$ & $75.9 \pm 2.5$ & $7.3 \pm 0.1^{*}$ & $9.9 \pm 0.14 *$ & $10.6 \pm 0.1^{*}$ \\
\hline $\begin{array}{l}\text { Periodontal index } \\
\text { of RA (in points) }\end{array}$ & $5.2 \pm 0.5$ & $2.3 \pm 0.3 *$ & $1.8 \pm 0.2 *$ & $1.2 \pm 0.3 *$ & $4.9 \pm 0.3$ & $2.1 \pm 0.3 *$ & $2.0 \pm 0.3 *$ & $1.6 \pm 0.3 *$ \\
\hline $\begin{array}{l}\text { Depth of } \\
\text { periodontal } \\
\text { pockets (in } \\
\text { points) }\end{array}$ & $5.69 \pm 0.6$ & $3.1 \pm 0.2 *$ & $1.8 \pm 0.2 *$ & $1.7 \pm 0.2 *$ & $5.72 \pm 0.6$ & $3.6 \pm 0.09 *$ & $2.7 \pm 0.3 *$ & $2.9 \pm 0.3 *$ \\
\hline
\end{tabular}

Note: ${ }^{*} \mathrm{p}<0.05$ - a significant difference with the indicators before treatment.

In control X-ray examinations carried out in the period of 11-12 months after treatment, the disappearance of destructive changes in the bone tissue of the alveoli was noted, with the appearance of smooth and clear contours of the interdental alveolar septa. It should be noted that the most pronounced dynamics of restoration of periodontal bone structures in patients of both groups was observed in the foci of diffuse active osteoporosis: there was an increase in bone density up to the restoration, clear detection of contours of the edges of the alveolaris processus in the areas of osteoporotic process and a slight increase in the height of the interdental alveolar septa.

The disappearance of areas of active osteoporosis, the restoration of the sharpness of the edges of the alveolaris processuses due to the compaction of bone structures, the formation of closing membranes, partial restoration of the height of the alveolaris processus were determined.
In the future, the evaluation of the effectiveness of the proposed methods of treatment of rapidly progressing generalized periodontitis was performed on the basis of the analysis of changes in laboratory parameters. After treatment in both groups of patients, along with the improvement of clinical indicators, there was a synchronous normalization of the levels of immunoglobulins of the main classes (SIgA, IgG and IgM) in the oral fluid.

Of particular interest among the indicators of local humoral immunity was the dynamics of changes in SIgA, as its level before treatment in patients of both groups was prone to a significant decrease (more than by 3.5 times), which indicated the presence of severe immunodeficiency and decrease in the barrier and microbicidal function of the oral mucosa. Comparative analysis of the dynamics of changes in SIgA values before treatment and immediately after it showed that at the end of 
treatment there was a significant increase in its levels in the oral fluid up to the normal range both in patients of the comparison and the main group (respectively $1.16 \pm 0.5 \mathrm{~g} / \mathrm{l} ; \mathrm{p}<0.05)$. Similar dynamics was observed in $\operatorname{IgM}$ and $\operatorname{IgG}$ values in patients of both groups (Table 2). Against the background of normalization of SIgA, IgG and IgM levels, the content of IgA in the oral fluid in patients of the main group after treatment did not change $(p<0.05)$ and in patients of the comparison group tended to significant decrease $(p<0.05)$ to the limits of the conditional norm.

It is very important that the levels of immunoglobulins and 6 months after treatment in patients of both groups were registered in the range of healthy ones in the absence of recurrence of the inflammatory process in the gum tissue, which was observed in more than $90.2 \%$ of the treated.

Thus, the proposed methods of treatment of rapidly progressing generalized periodontitis, by improving the protocol and using systemic enzyme therapy with Wobenzyme in combination with rhBMP-2 cause an adequate normalizing effect on the state of local humoral immunity, which, apparently, contributed to the effectiveness of the antibacterial effect of the antibacterial agents used.
The results of the study of the dynamics of changes in the cytokine profile in the treatment of patients with rapidly progressing generalized periodontitis were quite significant. The inclusion of combined immunocorrective therapy (comparison group) and systemic enzyme therapy (main group) in the treatment protocol helped to eliminate the imbalance in the functioning of cytokines immediately after treatment. In both groups the levels of IL-1 $\beta$, TNF- $\alpha$ and IL- 4 approached the control values (Table 2 ).

The materials presented in Table 2 testify to significant changes in the concentration of the studied cytokines relative to treatment $(p<0.05)$. At the end of treatment the levels of IL-1 $\beta$, TNF- $\alpha$ and IL-4 in the oral fluid corresponded to the range of fluctuations within healthy in $96.7 \%$ of patients of the comparison group and in $90 \%$ of patients in the main group, this testifies to identical effectiveness of treatment with improved protocol therapy and Wobenzyme monotherapy. Thus, after treatment the level of IL-1 $\beta$ in the oral fluid decreased in patients of the comparison group by 7.6 times, and in the main group - by 6.8 times.

Table 2

\section{Dynamics of cytokines IL-1 $\beta$, TNF- $\alpha$ and IL-4 content in patients with rapidly progressing generalized periodontitis of the main and comparison group (M $\pm m)$}

\begin{tabular}{|c|c|c|c|c|c|c|}
\hline \multirow{3}{*}{$\begin{array}{l}\text { Indicators of } \\
\text { cytokine status }\end{array}$} & \multicolumn{6}{|c|}{ Groups of subjects } \\
\hline & \multicolumn{3}{|c|}{ Comparison group $(n=31)$} & \multicolumn{3}{|c|}{ Main group $(n=30)$} \\
\hline & $\begin{array}{c}\text { before } \\
\text { treatment }\end{array}$ & $\begin{array}{l}1 \text { month after } \\
\text { treatment }\end{array}$ & $\begin{array}{c}6 \text { months after } \\
\text { treatment }\end{array}$ & before treatment & $\begin{array}{l}1 \text { month after } \\
\text { treatment }\end{array}$ & $\begin{array}{c}6 \text { months after } \\
\text { treatment }\end{array}$ \\
\hline IL-1ß (pg/ml) & $581.2 \pm 12.2$ & $76.7 \pm 5.5^{*}$ & $80.3 \pm 4.9^{*}$ & $602 \pm 13.1$ & $82.4 \pm 5.8^{*}$ & $99.3 \pm 14.0 *$ \\
\hline TNF- $\alpha(\mathrm{pg} / \mathrm{ml})$ & $353.4 \pm 10.7$ & $81.8 \pm 7.2$ & $73.2 \pm 5.0 *$ & $371.0 \pm 11.1^{*}$ & $80.1 \pm 6.1 *$ & $101.0 \pm 7.4 *_{* *}$ \\
\hline IL-4 (pg/ml) & $22.6 \pm 3.4$ & $60.9 \pm 4.1 *$ & $44.8 \pm 4.8 *$ & $20.8 \pm 3.2$ & $51.7 \pm 6.2$ & $38.8 \pm 4.1^{*}$ \\
\hline
\end{tabular}

Note: ${ }^{*} \mathrm{p}<0.05$ - reliable in relation to the data before treatment, ${ }^{* *} \mathrm{p}<0.05$ - reliable in relation to the data of the comparison group.

The content of TNF- $\alpha$ at the end of treatment significantly decreased in both groups: in the comparison group - by 4.3 times and in the main group by 4.6 times. Differences in the average values of TNF- $\alpha$ between groups were not detected $(\mathrm{p}<0.05)$.

The level of concentration of IL-4 in the oral fluid after treatment increased significantly compared with baseline in both groups and had no significant differences from the value of the con- ditional norm. The increase in the content of this indicator in patients of the comparison group was by 2.7 times, and in patients of the main group - by 2.5 times, but no significant differences were observed $(p<0.05)$. The obtained results give the right to assert that in the process of treatment of rapidly progressing generalized periodontitis both under the influence of an improved therapeutic complex, including combined immunocorrection and when 
using the developed method of treatment with Wobenzyme in the protocol, switching of synthesis of proinflammatory cytokines to anti-inflammatory occurs.

Due to the fact that IL-4 is an antagonist of IL-1 $\beta$ and TNF- $\alpha$, a simultaneous increase in this cytokine with a decrease in proinflammatory cytokines can be considered as a restoring of balance in the cytokine system in patients of both groups. Here it is appropriate to note that normalization of the levels of IL$1 \beta$, TNF- $\alpha$ and IL- 4 achieved after treatment remained stable for 6 months or more, both in patients of the main and the comparison group.

At the end of treatment in both groups there was a statistically significant decrease in the content of lipoperoxidation products in the blood plasma and an increase in the activity of antioxidant enzymes (Table 3). The content of lipid hydroperoxides and malonic dialdehyde in the group where Mexidol (comparison group) was used in the treatment protocol decreased by $56.1 \%$ and $63.9 \%$ and, accordingly, reached the level of healthy individuals. At the same time, the indicators of lipid peroxidation in patients taking Wobenzym ${ }^{\circledR}$ (main group) decreased by 3.3 times and 1.9 times, respectively at the end of treatment and almost approached the limits of the conditional norm.

Table 3

\section{Dynamics of LPO and AOS indicators in patients with rapidly progressing generalized periodontitis treated with advanced protocol therapy (comparison group) and systemic enzyme therapy in combination with rhBMP-2 (main group) (M $\pm m$ )}

\begin{tabular}{|c|c|c|c|c|c|c|}
\hline \multirow{3}{*}{$\begin{array}{c}\text { Indicators of LPO and } \\
\text { AOS }\end{array}$} & \multicolumn{6}{|c|}{ Groups of subjects } \\
\hline & \multicolumn{3}{|c|}{ comparison group $(n=31)$} & \multicolumn{3}{|c|}{ main group $(n=30)$} \\
\hline & $\begin{array}{c}\text { before } \\
\text { treatment }\end{array}$ & $\begin{array}{l}1 \text { month after } \\
\text { treatment }\end{array}$ & $\begin{array}{c}6 \text { months after } \\
\text { treatment }\end{array}$ & $\begin{array}{c}\text { before } \\
\text { treatment }\end{array}$ & $\begin{array}{l}1 \text { month after } \\
\text { treatment }\end{array}$ & $\begin{array}{c}6 \text { months after } \\
\text { treatment }\end{array}$ \\
\hline MDA (mmol / l) & $6.74 \pm 0.34$ & $2.02 \pm 0.4 *$ & $2.43 \pm 0.2 *$ & $6.99 \pm 0.3$ & $2.97 \pm 0.3 *$ & $3.14 \pm 0.2 *$ \\
\hline GPL (pl.u.ed) & $6.81 \pm 0.3$ & $3.71 \pm 0.2 *$ & $3.82 \pm 0.2 \%$ & $6.92 \pm 0.3$ & $4.18 \pm 0.3 *$ & $4.04 \pm 0.2 *$ \\
\hline SOD (U / mg Hb) & $7.7 \pm 0.5$ & $19.9 \pm 0.8^{*}$ & $18.3 \pm 0.5^{*}$ & $7.68 \pm 0.5$ & $17.2 \pm 0.6^{*}$ & $16.9 \pm 0.6^{*}$ \\
\hline Catalase (U / mg Hb) & $205.8 \pm 10.6$ & $596 \pm 6.1 *$ & $542.7 \pm 7.2 *$ & $206.2 \pm 10.3$ & $511.3 \pm 6.4 *$ & $502.4 \pm 6.8 *$ \\
\hline
\end{tabular}

Note. ${ }^{*} \mathrm{p}<0.05-$ a significant difference with the indicators before treatment.

The described dynamic changes in the content of malonic dialdehyde and lipid hydroperoxides significantly decreased in blood plasma under the influence of an improved protocol and proposed method of treatment of rapidly progressing generalized periodontitis, obviously they should be considered as an indicator of completion of the inflammatory process in periodontal tissues.

The study of antioxidant status in patients with rapidly progressing periodontitis after advanced protocol therapy revealed an increase in the activity of antiradical enzymes: superoxide dismutase - by 2.6 times and catalase - by 1.9 times. The average values of SOD and catalase in patients of the comparison group directly and in 6 or more months after treatment almost did not differ from those in healthy people $(p>0.05)$, which indicated a positive trend, apparently associated with the elimination of inflammatory-destructive process in the periodontium and clinical remission of the disease.

In patients receiving systemic enzyme therapy, there was also a positive dynamics in the indicators of LPS and AOS, but somewhat less pronounced. The content of malonic dialdehyde and lipid hydroperoxides in blood plasma after treatment decreased by 2.4 times and 1.7 times, respectively. At the same time, the analyzed patients showed an increase in SOD of erythrocytes by 2.3 times and erythrocyte catalase - by 2.5 times.

The above data indicate that in patients of the main group after treatment with Wobenzyme systemic enzyme therapy the dynamics of SOD and catalase activity in erythrocyte plasma, MDA and GPL in blood plasma had no significant differences 
compared with those in the comparison group who received an improved standart (protocol) therapy.

Follow-up after 6 months or more noted the stabilization of POL-AOS in patients of both groups, which was regarded as a positive result of the treatment measures that guarantee the stability and duration of clinical remission.

Thus, the study of the dynamics of clinical, immunological and biochemical parameters proves that the use of advanced protocol treatment complex and the use of the developed method of drug treatment, including the use of systemic enzyme therapy in combination with rhBMP-2, allows to optimize the treatment of aggressive (rapidly progressing) generalized periodontitis.

Additional inclusion in the standard protocol therapy of combined immunocorrection of Polyoxidonium and Lycopid, as well as osteoinductor Osteogenon, has a pronounced clinical and corrective effect on humoral immunity, activity of free radical oxidation, imbalance in the cytosynthesis system and remodeling.

The performed studies demonstrate a similar effectiveness of the developed method of treatment of rapidly progressing generalized periodontitis, which envisages the replacement of numerous and diverse pharmacodynamically drugs of protocol therapy with systemic enzyme therapy - Wobenzyme $^{\circledR}$ in combination with rhBMP-2.

\section{CONCLUSIONS}

1. A comparative analysis of clinical, immunological and biochemical studies shows that the use of systemic enzyme therapy with Wobenzyme in the complex treatment of acute chronic generalized periodontitis has a pronounced therapeutic effect, which can be compared with that of standard polymedicine therapy, as it makes identical main pathogenetic links of the disease, contributes to the elimination of the inflammatory process in the gingival tissue in a short time and a long-term clinical and radiological stabilization of the results achieved in more than $90 \%$ of subjects.

2. The effectiveness of systemic enzyme therapy in combination with rhBMP-2 in patients with aggressive (rapidly progressive) generalized periodontitis is comparable to the clinical and laboratory effect obtained with the use of advanced protocol treatment, and is characterized by a rapid (on average $13.7 \pm 0.7$ days) elimination of active inflammatory-destructive process, normalization of local humoral immunity, cytokine profile, free radical oxidation and antioxidant defense system, achievement of clinical and radiological remission in more than $90 \%$ of patients.

Conflict of interest. The authors declare no conflict of interest.

\section{REFERENCES}

1. Antomonov M. [Mathematical processing and analysis of biomedical data]. 2nd ed. Kyiv: MIC «Medinform». 2018. p. 579. Russian. ISBN 978-966-409-202-6

2. Gudaryan A, Kuznyak N, Dronik I. [Clinical and laboratory efficacy of systemic enzyme therapy in patients with chronic generalized periodontitis complicated by purulent foci in soft periodontal tissues]. Medicni perspektivi. 2017;XXII(2):104-10. Russian.

doi: https://doi.org/10.26641/2307-0404.2017.2.109843

3. Zabolotnyi TD, Bandrivskii JuL, Dyryk VT. [The state of local and systemic immunity in patients with different course of generalized periodontitis]. Stomatologiya. 2016;95(6):23-25. Russian.

doi: https://doi.org/10.17116/stomat201695623-25

4. Miklyaev SV, Leonova OM, Glazev VK, et al. [Study of the quality of life in patients suffering from chronic inflammatory periodontal diseases]. Vestnik Tambov University: Natural and technical sciences. 2017;22(1):187-92. Russian.

doi: https://doi.org/10.20310/1810-0198-2017-22-1-187-192

5. Ushnitsky ID, Ivanova AA, Pinelis IS, Yurkevich AV, Mikhalchenko DV. [Modern etiological and pathogenetic aspects of inflammatory destructive proces- ses of periodontal tissues]. Endodontics Today. 2019;17(4):46-49. Russian.

doi: https://doi.org/10.36377/1683-2981-2019-17-4-46-49

6. Ulitovskii SB, Alekseeva ES. [Periodontal diseases: hygienic aspects of an integrated approach to treatment]. Medecinskii alfavit. 2019;2(11):22-26. Russian. doi: //doi.org/10.33667/2078-5631-2019-2-11(386)-22-26

7. Bartold PM, Van Dyke TE. An appraisal of the role of specific bacteria in the initial pathogenesis of periodontitis. J Clin Periodontol. 2019;46:6-11. doi: https://doi.org/10.1111/jcpe.13046

8. Cirino CCDS, Vale HFD, Casati MZ, Sallum EA, Casarin RCV, Sallum AW. Clinical and Microbiological Evaluation of Surgical and Nonsurgical Treatment of Aggressive Periodontitis. Braz Dent J. 2019;30(6):577-86. doi: https://doi.org/10.1590/0103-6440201902930

9. Marzin T, Lorkowski G, Reule C, et al. Effects of a systemic enzyme therapy in healthy active adults after exhaustive eccentric exercise: a randomised, two-stage, double-blinded, placebo-controlled trial. BMJ Open Sport Exerc Med. 2017;2(1):e000191. 2017 Mar 12. doi: https://doi.org/10.1136/bmjsem-2016-000191

10. Llanos AH, Silva CGB, Ichimura KT, et al. Impact of aggressive periodontitis and chronic periodontitis 
on oral health-related quality of life. Braz Oral Res. 2018;32:e006.

doi: //doi.org/10.1590/1807-3107bor-2018.vol32.0006
11. Kinane D, Stathopoulou P, Papapanou P. Periodontal diseases. Nat Rev Dis. 2017;3:17038. doi: https://doi.org/10.1038/nrdp.2017.38

\section{СПИСОК ЛІТЕРАТУРИ}

1. Антомонов М. Ю. Математическая обработка и анализ медико-биологических данных. 2-е изд. Київ: МИЦ «Мединформ». 2018. 579 с. ISBN 978-966-409-202-6

2. Гударьян А. А., Кузняк Н. Б., Дроник И. И. Клинико-лабораторная эффективность системной энзимотерапии у больных хроническим генерализованным пародонтитом, осложненным гнойными очагами в мягких тканях пародонта. Медичні перспективи. 2017. Т. XXII, № 2. С. 104-110. DOI: https://doi.org/10.26641/2307-0404.2017.2.109843

3. Заболотный Т. Д., Бандривский Ю. Л., Дырык В. Т. Состояние местного и системного иммунитета у больных с разным течением генерализованного пародонтита. Стоматология. 2016. Т. 95, № 6. С. 2325. DOI: https://doi.org/10.17116/stomat201695623-25

4. Изучение качества жизни у пациентов, страдающих хроническими воспалительными заболеваниями пародонта / С. В. Микляев и др. Вест. Тамбовского университета. Сер.: Естественные и технические науки. 2017. Т. 22. Вып. 1. С. 187-192. DOI: https://doi.org/10.20310/1810-0198-2017-22-1-187-192

5. Современные этиологические и патогенетические аспекты воспалительно-деструктивных процессов тканей пародонта / И. Д. Ушницкий и др. Эндодонтия Today. 2019. Т. 17, № 4. С. 46-49. DOI: https://doi.org/10.36377/1683-2981-2019-17-4-46-49

6. Улитовский С. Б., Алексеева Е. С. Заболевания пародонта: гигиенические аспекты ком- плексного подхода в лечении. Мед. алфавит. 2019;2(11):22-26.

DOI: //doi.org/10.33667/2078-5631-2019-2-11(386)-22-26

7. Bartold P. M., Van Dyke T. E. An appraisal of the role of specific bacteria in the initial pathogenesis of periodontitis. J Clin Periodontol. 2019. Vol. 46. P. 6- 11. DOI: https://doi.org/10.1111/jcpe.13046

8. Clinical and Microbiological Evaluation of Surgical and Nonsurgical Treatment of Aggressive Periodontitis / C. C. D. S. Cirino et al. Braz Dent J. 2019. Vol. 30, No. 6. P. 577-586.

DOI: https://doi.org/10.1590/0103-6440201902930

9. Effects of a systemic enzyme therapy in healthy active adults after exhaustive eccentric exercise: a randomised, two-stage, double-blinded, placebo-controlled trial / T. Marzin et al. BMJ Open Sport Exerc Med. 2017. Vol. 2, No. 1. P. e000191.

DOI: https://doi.org/10.1136/bmjsem-2016-000191

10. Impact of aggressive periodontitis and chronic periodontitis on oral health-related quality of life / A. H. Llanos et al. Braz Oral Res. 2018. Vol. 32. P. e006. DOI: https://doi.org/10.1590/1807-3107bor-

2018.vol32.0006

11. Kinane D., Stathopoulou P., Papapanou P. Periodontal diseases. Nat Rev Dis Primers 3. 2017. P. 17038. DOI: https://doi.org/10.1038/nrdp.2017.38

The article was received 2020.03 .23 